\title{
REVIEW OF MOBILE BANKING SOLUTIONS INCLUDING THE ANALYSIS OF SURVEY PERFORMED AMONG THE INDIVIDUAL USERS
}

\author{
Jolanta Panas, Katarzyna Wilczyńska \\ Warsaw School of Economics, Collegium of Management and Finance \\ Abstract. The article presents the structure of the electronic banking with attention being given to solutions applied in mobile banking and mobile \\ payments available in Poland. For the purpose of this article a survey was conducted among the active users of the Internet, aiming to research changes \\ with regards to susceptibility of individual users to take advantage of application of mobile banking including mobile payments and their main concerns \\ regarding the using of mobile banking services.
}

Keywords: online banking, mobile applications, near field communication

\section{PRZEGLĄD ROZWIĄZAŃ BANKOWOŚCI MOBILNEJ NA TLE BADAŃ ANKIETOWYCH PRZEPROWADZONYCH WŚRÓD UŻYTKOWNIKÓW INDYWIDUALNYCH}

\begin{abstract}
Streszczenie. Artykut przedstawia strukturę bankowości elektronicznej z uwzględnieniem rozwiąań stosowanych w bankowości mobilnej oraz płatnościach mobilnych dostępnych $w$ Polsce. Na potrzeby niniejszego artykulu przeprowadzono ankietę pośród użytkowników sieci Internet mająca na celu zbadanie zmian zachodzacych $w$ zakresie skłonności indywidualnych użytkowników do korzystania z usług bankowości mobilnej, w tym z płatności mobilnych oraz ich głównych obaw związanych z korzystaniem z ustug bankowości mobilnej.
\end{abstract}

Słowa kluczowe: bankowość online, aplikacje mobilne, komunikacja bliskiego zasięgu

\section{Introduction}

The mobile banking services market is one of the most dynamically developing banking services markets in Poland and the use of mobile payments by Poles has already become a common phenomenon. Thus, it can be said that Poles prefer increasingly non-cash transactions. Intuitive for users, easily available applications and mobile devices, uncomplicated transaction initiation as well as security, simultaneously impact the continuous increase in the number of payments made by using various types of mobile solutions. The multitude of available solutions, the diversity of applied technologies and the varying level of awareness and trust of banking customers for mobile banking services make it necessary to constantly update and systematize knowledge in this area. The article presents the structure of electronic banking with particular emphasis on solutions used in mobile banking and mobile payments.

In addition to presenting the current state of the mobile banking services market in Poland, the important objective of the study was to review the most important technologies and innovative mobile solutions, with particular emphasis on the security aspect, as well as the ubiquity and development potential of individual solutions.

The article also discusses the dependence of mobile devices adoption rate on mobile devices penetration rate and mobile connection speed, based on the example of Poland as well as selected countries and regions of the world.

Moreover, for the purpose of this study, in November 2018 the research among individual users were carried out, aimed at examining changes in individual users' tendencies to use mobile banking services on a daily basis as well as users concerns and doubts regarding mobile payments. The results of the survey are presented in several different perspectives and the conclusions presented can become the starting point for further research in this area.

\section{Review of electronic banking services from terminal banking to mobile payments}

In order to identify the stages of development of mobile banking in Poland, it is worth looking through the structure of electronic banking.

Electronic banking provides the user with unlimited in time and location-independent access to the bank account via electronic devices. Electronic banking is divided into terminal banking, Internet banking and mobile payments [12].

\subsection{Terminal banking}

Terminal banking is the oldest form of electronic banking. It allows access to bank accounts via electronic devices and conduct transactions using payment cards. The devices used in terminal banking include: ATMs, multimedia kiosks, and electronic payment terminals, also known as a Point of Sale (POS). Whereas, among payment cards, in terms of functionality, are distinguished: debit, credit, charge, pre-paid and multi-currency cards. Forms of payment with the use of payment cards are developing dynamically. The new ones among the payment cards include multicurrency cards - debit cards issued to one bank account maintained both in the Polish currency and in a foreign currency. They allow conduct transactions abroad in very convenient way, where the settlement of the transaction is carried out automatically (in national currency or in a foreign currency) from the relevant customer account. When making a transaction with this type of card, the customer is charged exactly the amount he/she would have paid in a foreign currency (without the need of conversion) [21]. This card has a microprocessor that ensures a high level of security of transactions. Online transactions can be authorized using the 3-D Secure mechanism, it means customer identification by additional generation of an unique password, sent to mobile device, for example to a mobile phone [6]. Multicurrency cards are offered, among others, by following banks: PKO BP, Bank Pekao, ING Bank Śląski. Another novelty among multicurrency cards is the solution popularized by the method of Revolut, requiring the installation of a dedicated application that allows converting currency into a selected foreign currency bypassing spreads.

The first payment cards in terms of technology were magnetic cards, which are in use for over 50 years [7]. The magnetic card carries the risk of easy duplicating. An electronic card with a builtin contact microprocessor has a built-in chip, which makes duplicating it difficult. There is also an electronic card with a built-in proximity microprocessor, where the data from the card is read by contactless using electromagnetic waves.

The characteristic feature of these cards is high data protection, speed of service and flexibility, enabling efficient data modification [18]. Currently, electronic cards replace magnetic cards - at the end of June 2018, contactless cards accounted for $81,7 \%$ of all cards in Poland, which means that only every fifth card is not equipped with the proximity payment function [20]. The proximity transactions conducted via payment cards, use Near Field Communication (NFC) technology, which enables sales 
transactions to be carried out without entering a PIN, while maintaining the amount limits [8]. NFC technology allows you to quickly send small data packets with payment information up to a maximum distance of ten centimeters, using radiocontrolled microchips [19].

Contactless payments in our country are becoming more and more popular. According to the National Bank of Poland, the share of proximity payments in the total number of non-cash payments in the first half-year of 2018 amounted to $73 \%$ and in comparison to the first half-year of 2017 it increased by $33 \%$. On the other hand, the share of contactless transactions in total turnover of non-cash transactions carried out with cards amounted to $57 \%$ and in comparison to the first half-year of 2017 it increased by as 53\% [20]. One of the main advantages of proximity cards is that the card is not passed to the seller and the customer has it all the time in his/her hand. Moreover, the risk of skimming in contactless transactions is eliminated because there is no contact between the proximity card and the reader. There are already ATMs with NFC technology on the Polish market - they are offered, among others, by the Planet Cash and Euronet ATM network.

Additionally, in order to increase even more non-cash turnover among citizens, are carried out nationwide educational and information campaigns such as polskabezgotówkowa.pl and wartobezgotówkowo.pl, increasing the awareness of Poles concerning the safety and mechanisms of non-cash transactions [14].

According to a recent survey carried out by the IBRIS Institute, $19 \%$ of Poles do not use cash, and $33 \%$ of people before the age of 26 confirm that they only use electronic forms of settlement [16].

\subsection{Internet banking}

Another form of electronic banking is the Internet banking, which is characterized by the use of the Internet by bank to provide financial services in a remote way, regardless of the interaction time and the actual location of the transaction parties. The following stages of the Internet banking development are distinguished [12]:

- Bank 0.0. - the Internet network as a medium for presenting the offer of bank services with a reference to bank branches, aiming to mitigate the staff and reduce the time of service in the branch;

- Bank 1.0. - the Internet network allows access to basic banking services with the possibility of performing remote transactions with a very large limitation of support from the bank;

- Bank 2.0. - providing an interactive and multidimensional platform for the provision of financial and non-financial services, with a simultaneous comprehensive analysis of customer demand preferences, which enables optimization of client management methods and establishing relationships with clients [5];

- Bank 3.0. - full personalization of the service, and even anticipation of customer expectations, thanks to the possibility of real-time processing of information from many sources (among others social networks, e-mail, multimedia files or text streams). Owing to this, it is possible to conduct a predictive analysis. Safes using biometric techniques such as iris scanning, voice recognition techniques are consequently becoming increasingly common [12].

Taking into account the technical measures enabling users the remote access to the bank's services, the Internet banking distinguishes: desktop banking, online banking, mobile banking [12].

Desktop banking requires that the user install dedicated software that allows remote access to the bank's services. It is usually addressed to customers who do not have access to a permanent Internet connection, because thanks to the installed software, data is also stored on the client's side and there is the possibility of conducting a passive transaction in off-line mode.

Online banking is currently the most common form of the Internet banking. It does not require from the client to install special software, but it entail meeting of the technical condition, which is to connect in real time (on-line), via the Internet with the bank's server.

Mobile banking provides remote access to services provided by the bank via mobile Internet and mobile devices such as tablets, smartphones or phablets (a hybrid device that combines the functions of a small tablet with a smartphone; it has a screen larger than the smartphone and smaller than the tablet, in the range of 5 to 7 inches). From all forms of the Internet banking, the mobile banking removes the most the place and time barriers while providing the remote services. Very rapid development of mobile banking in the modern world is possible due to significant progress in the offered data transfer speed via mobile Internet and the increasingly common use of mobile devices, which are usually cheaper than desktop or portable computers, and above all they are constantly within the user's reach. The key technologies enabling the provision of banking services using mobile devices are:

- Short Message Service (SMS),

- Internet light,

- Mobile Applications (Mobile App),

- Responisive Web Design (RWD).

SMS technology is the oldest and the simplest mobile banking technology. Communication between the bank and the customer takes place via short text messages. Thanks to the Internet light technology, the use of mobile banking in the Internet light channel is very similar to online banking, but the range of mobile banking services is not the same and depends on the bank's decision. Due to the limited speed of the mobile Internet, special Internet sites have been created, enabling faster loading of lighter pages, which are maximally simplified and free of graphic elements. Access to the account takes place by logging into the light bank's website. The major weaknesses of this technology include: uncomfortable navigation, the threat of hacking confidential data by hackers via fake websites (called as phishing), a long process of accessing a bank account, no integration with other smartphone functions, i.e. a QR code reader, a GPS signal for geolocation of ATMs and branches. Light technology meets the requirements of customers who occasionally use it, without the need to install additional software, such as a mobile application. Thanks to the mobile application, communication between the bank and the customer takes place through a dedicated application installed on the mobile device. There is a less dependence on the quality of mobile Internet, because the graphical interface is stored in the application, and only the most important data is downloaded from the bank's server, which makes the mobile application much faster than the light Internet websites. The most important advantages of mobile applications are: improve service comfort, intuitive graphical interface, lower data transfer costs, automatic update, additional functionalities thanks to integration of the mobile application with other smartphone functions (e.g. defining transfers using the recipient's phone number). It should be emphasized that in mobile applications used to provide banking services, the connection to the bank's server is based on additional security schemes, thanks to which the level of security is much higher than in the case of banking services from the bank's website, for example the threat of abuse by phishing is lower [12]. The main shortcomings of mobile applications include the fact that its use is based on the level of awareness of the client downloading the application. In addition, the application is protected by an independent password, which for many customers is an obstacle in the form of multi-password in access to banking services (e.g. a different password for online banking, and others for the bank's mobile application). Moreover, due to the variety of operating systems in mobile devices, there is a need to prepare several versions of mobile applications and ensure their regular updates, which 
significantly increases costs on the bank's side. Responsive Web Design (RWD) are based on lite technology, allowing automatic adjustment of resolution, graphics, page content to the recognized mobile device, in order to ensure maximum usability of content and high navigation comfort. RWD technology enables to combine the functionality of the web banking with the functionality of the mobile application. The basic disadvantages of this technology include the lack of integration with other smartphone functions. Bank customers more and more often reach for mobile applications, in order to have access to their money at any time [11].

\subsection{Mobile payments}

Mobile payments allow the user to transfer funds using a mobile device. Consumers use mobile devices to make a money transfer instead of based on common payment methods such as cash, checks or payment cards [3]. Currently, there is a very large diversity of mobile payment models, both in terms of technological solutions as well as entities involved in transaction processing.

Taking into account the implementation of payments it is distinguished two basic types of mobile payments [12]:

- Remote payments - the location of the entities making the transaction is irrelevant because there is no direct contact between the payer and the beneficiary of the payment (i.e. the Internet, SMS).

- Proximity payments - the location of the entities making the payments is important, because the transfer of data between the payer and the beneficiary is carried out at a very close distance (i.e. NFC, HCE technology, QR codes).

Though, taking into account the status of the entities making the transaction, we distinguish mobile payments between [12]:

- natural person (person to person - P2P),

- entrepreneurs (business to business - B2B),

- customers and entrepreneurs (customer to business - C2B),

- customers and self-service devices (customer to machine-C2M),

- between two devices (machine to machine-M2M).

Mobile payment systems are also divided due to the place of money storage - in this way payments are based on [12]:

- bank account (payment based on the balance of available customer funds on the account, used by banks),

- payment card account (payment is processed from the card account),

- prepaid account (used by non-bank system operators),

- billing system (mainly used by mobile operators).

The most developed mobile payment systems currently support the commercial transactions $(\mathrm{C} 2 \mathrm{~B})$ and the cash transfers $(\mathrm{P} 2 \mathrm{P})$. The main reason for the development of this type of mobile payment systems is the growing interest in mobile commerce (m-commerce), as well as searching by customers for more and more convenient and safe non-cash payment methods. The constant introduction of new technological solutions in mobile payments is aimed not only at increasing the functionality of services, but also providing even better comfort to users, while maintaining the necessary, often more and more restrictive, security rules.

\subsection{Technological solutions in mobile payments}

NFC technology is primarily used in mobile payments based on the use of mobile phones (the so-called sim-centric model, SIM NFC). The transaction is conducted by the application installed in the memory of the mobile phone, making contact with the so-called a secure element, stored on the SIM card containing the client's virtual payment card data [8]. Transactions based on the SIM NFC technology provide the user with the integration of the payment medium with the smartphone [12]. Despite the high popularity, one of the main drawbacks of the SIM NFC model is the need to engage telecommunications operators in the service launch process, because the virtual card data is directly linked to the SIM card. A more modern mobile payment solution is NFC technology in the Host Card Emulation (HCE) module, where confidential data of the virtual card is saved in the mobile application, not on the SIM card. Thanks to this there is no need of service activation by the mobile operator. The confidential data necessary for transaction authorization is stored in a computing cloud, which is characterized by high security standards, much higher than in the case of a secure element in the SIM card. When conducting mobile payments, the smartphone works like a payment card, using the tokenization process - the mobile application transfers to the terminal data allowing authorization of only a single transaction (tokens) that are authorized by the bank remotely (the so-called tokenization process) [12].

Another form of contactless payments are payments using QR codes. Payment with $\mathrm{QR}$ code is intuitive and requires from the client to scan the graphic code using the correct reader from the mobile device display. QR codes are very versatile, as they allow for proximity transfer of various data, including those used to authorize payments. A big advantage of payments with QR codes is automation of the process - no one-time passwords are entered, which significantly extend the transaction and generate the risk of making a mistake and rejecting the transaction. Another technological solution for mobile payments is the mobile wallet, which is an electronic version of the consumer billfold. It enables convenient and quick transactions without having to provide data from a debit or credit card each time. Currently, mobile payments using the mobile wallet can be provided, for example, by: Apple Pay, Google Pay, Samsung Pay, MasterPass, and Visa Checkout.

An interesting and at the same time gaining popularity solution enabling mobile payments without the use of a payment card, based on the system of one-time codes generated in a mobile application is the BLIK system. It is a modern system for conducting mobile payments and is a perfect example of cooperation, as six banks, that are competing with each other on a daily basis, joined forces and created a common mobile payment standard. In 2013 Alior Bank, Bank Millennium, Bank Zachodni WBK (currently Santander), ING Bank Śląski, mBank and PKO Bank Polski concluded an agreement on a uniform standard of mobile payments. As a result, an offer was created that was directed to the entire banking market in Poland. The founders became shareholders of this mobile system, while the entity responsible for its operational service and guaranteeing the Information and Communication Technologies (ICT) infrastructure, is the National Clearing House [4]. In this way, Poland has strengthened its position in the world of global leaders creating innovative payment solutions. BLIK payments are a very convenient method of payment and are very popular among customers due to its simplicity and convenience. According to the Polish Payment Standard, in the third quarter of 2018 BLIK payments accounted for over 24.3 million transactions, which is a threefold increase compared to the previous year [15]. In order to make a payment using the BLIK system, you must install the mobile banking application of one of the banks participating in the project. Then, for each transaction, a six-digit one-time code is generated, which is valid for only two minutes. Additionally, in order to complete the transaction, both information about the amount and the name of the acceptance point must be confirmed by the user in the mobile application.

Without any doubts, the BLIK mobile payment system has revolutionized the Polish non-cash payment market. In addition, work is currently underway on another revolutionary technological solution in the world of mobile payments, in which the smartphone will be used as a payment terminal. In April 2018, Mastercard started a pilot program in Poland testing a solution called SoftPOS, using a smartphone as a payment terminal. Thanks to such a revolution, entrepreneurs will gain access to the most modern solutions in the field of mobile payments, while minimizing the cost of maintaining the device. 


\section{Mobile payments adoption rate in relation to selected favourable technical conditions}

The rising number of the Internet users as well as rapidly evolving technology used in financial sector have led to the digitization of many banking products. The available information regarding current Internet penetration rate worldwide differs depending on the source of data and assumptions adopted by the particular investigators of this factor. Due to the fact that the majority of international organizations as well as national statistical institutes publish the official data on the Internet usage with a significant delay, it is worth using the results provided by globally recognized statistical portals. According to Reuters, as of January 1, 2018, a total number of the global Internet users was approximated to be $3,812,564,450$ [22] what constitutes the Internet penetration rate at $50 \%$ of the world's population. In turn, the global social media management platform Hootsuite cooperating with global agency We Are Social present statistic of digital population worldwide as of October 2018, indicating that almost 4,176,000,000 people were active Internet users [20] (ca. $55 \%$, of the world's population, taking 7.6 billion people as world population in respective period). Referring to the Cisco VNI Global IP Traffic Forecast the global Internet traffic will grow 3.7-fold from 2017 to 2022 at the compound annual growth rate (CAGR) of $30 \%$ [1]. It is forecasted that share of PCs to the total global Internet traffic will drop from $49 \%$ in 2017 to $19 \%$ by 2022 , whereas $50 \%$ of the total global Internet traffic by 2022 will be generated through smartphones (up from $23 \%$ in 2017) [1]. In addition, the anticipated increase in networked devices per capita - globally, there could be up to 3.6 networked devices per capita in 2022 [1], is accompanied by continuously accelerating broadband speeds.

Assuming that the number of mobile networked devices per capita will have a significant impact on mobile payments adoption rate, it should be noted that the highest adoption of mobile networked devices are forecasted in North America, while the lowest - in Middle East \& Africa. The more detailed forecast of networked devices ratio analysed by region is presented in the Table 1 .

Table 1. Number of networked devices per capita in 2022 by region (forecast)

\begin{tabular}{|l|r|r|}
\hline \multicolumn{1}{|c|}{ Region } & \multicolumn{1}{c|}{$\begin{array}{c}\text { Networked devices } \\
\text { per capita }\end{array}$} & \multicolumn{2}{c|}{$\begin{array}{c}\text { Mobile networked } \\
\text { devices per capita }\end{array}$} \\
\hline North America & 13.4 & 3.1 \\
\hline Western Europe & 9.4 & 2.7 \\
\hline Central \& Eastern Europe & 3.9 & 1.8 \\
\hline Asia Pacific & 3.1 & 1.5 \\
\hline Latin America & 2.9 & 1.5 \\
\hline Middle East \& Africa & 1.4 & 1.0 \\
\hline
\end{tabular}

Source: own elaboration based on data published by Cisco Systems [1]

Narrowing the above presented analysis only to selected countries, it can be noticed that the average possession of mobile networked devices as well as accelerating mobile connection speeds create favourable technical conditions for the widespread use of mobile services, including mobile payments in each of the selected countries.

The Table 2 presents forecasted adoption of mobile networked devices, forecasted average mobile connection speed and share of online users likely to use mobile payments on smartphones in the following countries: the United States of America (USA), Canada, the Federal Republic of Germany (Germany), the French Republic (France), the United Kingdom of Great Britain and Northern Ireland (UK), the Republic of Poland (Poland), the Italian Republic (Italy), the Kingdom of Sweden (Sweden), the Russian Federation (Russia), the People's Republic of China (China), the Republic of India (India), Japan, the Federative Republic of Brazil (Brazil), the United Mexican States (Mexico), the Unitary State of the Republic of Indonesia (Indonesia) and the Republic of South Africa (South Africa).
Table 2. Number of mobile networked devices per capita and average mobile connection speed in 2022 in the selected countries (forecast) versus share of online users likely to use mobile payments as of March 2018

\begin{tabular}{|c|c|c|c|}
\hline Country & $\begin{array}{l}\text { Mobile networked } \\
\text { devices per capita* }\end{array}$ & $\begin{array}{l}\text { Average mobile } \\
\text { connection speed* }\end{array}$ & $\begin{array}{l}\text { Share of online } \\
\text { users likely to use } \\
\text { mobile payments } \\
\text { on smartphones** }\end{array}$ \\
\hline USA & 3.1 & 39 Mbps & $45 \%$ \\
\hline UK & 3.1 & 40 Mbps & $39 \%$ \\
\hline Germany & 2.9 & $44 \mathrm{Mbps}$ & no data \\
\hline Sweden & 2.9 & 49 Mbps & $64 \%$ \\
\hline Japan & 2.8 & 32 Mbps & $29 \%$ \\
\hline Russia & 2.8 & $20 \mathrm{Mbps}$ & $71 \%$ \\
\hline Italy & 2.8 & $41 \mathrm{Mbps}$ & $36 \%$ \\
\hline France & 2.6 & $40 \mathrm{Mbps}$ & $31 \%$ \\
\hline Canada & 2.3 & $69 \mathrm{Mbps}$ & $36 \%$ \\
\hline Poland & 2.2 & $33 \mathrm{Mbps}$ & $78 \%$ \\
\hline South Africa & 1.9 & $26 \mathrm{Mbps}$ & $75 \%$ \\
\hline China & 1.8 & $55 \mathrm{Mbps}$ & $94 \%$ \\
\hline Indonesia & 1.6 & $15 \mathrm{Mbps}$ & $93 \%$ \\
\hline Brazil & 1.5 & $20 \mathrm{Mbps}$ & $69 \%$ \\
\hline Mexico & 1.2 & $21 \mathrm{Mbps}$ & $68 \%$ \\
\hline India & 1.0 & $10 \mathrm{Mbps}$ & $83 \%$ \\
\hline World & 1.5 & $29 \mathrm{Mbps}$ & $60 \%$ \\
\hline
\end{tabular}

Source: own elaboration based on data published by Cisco Systems [1]

and Statista [13]

* forecast for 2022, ** as of March 2018

As it can be counted using statistical methods, the share of the Internet users in selected countries who are likely to use mobile payment systems or applications on their smartphone in the next year is not significantly correlated with neither mobile networked device per capita ratio nor with average mobile connection speed.

However, it is worth noticing that despite low forecasted mobile networked devices penetration ratio as well as the slowest mobile connections among above listed countries, 93\% of respondents from Indonesia stated that they were likely to use mobile payments in the next year.

A detailed study of the relationship between mobile devices penetration rate, mobile connection speed and mobile banking adoption in the selected country could be the subject of further research, because this subject has not yet been further explored and described. However, it should be emphasised that extensive researches have been developed in order to understand the following factors that influence mobile banking user adoption: perceived usefulness, perceived ease of use, trust, social influence, perceived risk, self-efficacy, facilitating conditions, resistance and selected demographic factors [13]

\section{Results of the survey conducted among the active Internet users}

For the purposes of this study, a survey was conducted in order to examine changes in individual users' tendencies to use mobile banking services (including mobile payments) on a daily basis. One of the most important elements of the conducted research was gathering opinions on the main concerns related to the use of mobile banking services, as well as identifying potential future situations in which the Internet users would be most likely to use mobile payments. The survey was conducted in the form of an online survey - the respondents filled out an interactive questionnaire, which contained 5 closed questions (both single and multiple-choice), as well as their age, sex, position and place of residence. The survey was conducted from 12 to 21 November 2018 and was anonymous.

In order to ensure the most consistent understanding of the key issues contained in the questionnaire, the form has been provided with a short introduction, which includes the following original definitions:

- mobile banking or mobile banking services are defined as all banking services that can be used by the user through mobile devices. According to the adopted definition, a mobile 
banking user is both a user using mobile applications and RWD services (Responsive Web Design - a solution based on lite web design, enabling automatic adjustment of page resolution to a mobile device), as well as a user using a standard bank transaction system through mobile device (phone, tablet, watch, etc.),

- mobile payments in this survey should be understood as any charges or fees for a product or service that are carried out via mobile technologies (including SMS, WAP, USSD, NFC, HCE); in particular: online payments initiated via mobile devices, payment cards (including credit cards, gift cards, travel cards) and services such as PayPal, Apple Pay, Google Wallet, Samsung Pay, BLIK services - for the purposes of this study, cash transactions are not included in the definition of mobile payments.

\subsection{Characteristics of the research sample}

The study was conducted among selected group of people - professionally active adult Internet users as well as students and $\mathrm{PhD}$ students. In the further part of the study, this selected group of people is also referred to as respondents or surveyed Internet users. It should be emphasized that the survey was intentionally sent to respondents with preferably higher, postsecondary education, who are living in large cities and have established professional position. In order to ensure full anonymity of the questionnaire, the respondents should provide their gender, age, place of residence and position held.

In the period from November 12 to November 2018, 200 complete sets of answers to the questionnaire questions were collected. The basic characteristics of the test sample were determined after the end of the response-recording period detailed data is presented in Figure 1, Table 3 and Table 4.

Respondents bygender and age

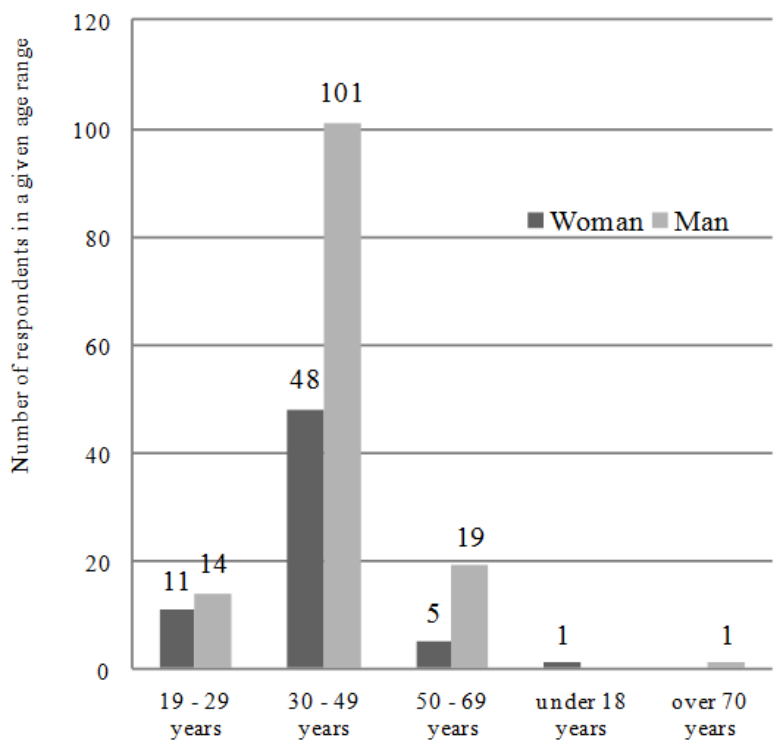

Declared age of the respondents

Fig. 1. Respondents by gender and age

As can be observed from the data presented in Figure 1, the dominant group among the survey's respondents were men ( $67.5 \%$ of the total number of respondents), while the most strongly represented age group were respondents of both genders aged from 30 to 49 years, who have accounted for a total of $74.5 \%$ of all respondents.

Due to the use of the pre-selection of respondents at the stage of survey's distribution, it is important to present the structure of the respondents' group in the perspective of their professional activity. Number and share of respondents holding a given position is illustrated in Table 3 .
Table 3. Number and share of respondents holding a given position

\begin{tabular}{|l|r|r|}
\hline $\begin{array}{l}\text { Position } \\
\text { (declared by respondents) }\end{array}$ & $\begin{array}{c}\text { Number of } \\
\text { respondents }\end{array}$ & $\begin{array}{c}\text { Share of } \\
\text { respondents }\end{array}$ \\
\hline Manager & 72 & $36.0 \%$ \\
\hline Member of senior management/supervisory board & 52 & $26.0 \%$ \\
\hline Specialist, expert, consultant & 42 & $21.0 \%$ \\
\hline Freelancer (incl. lawyer, doctor, artist) & 13 & $6.5 \%$ \\
\hline Other position & 8 & $4.0 \%$ \\
\hline Teacher, researcher & 4 & $2.0 \%$ \\
\hline Student, PhD student & 4 & $2,0 \%$ \\
\hline Worker & 3 & $1.5 \%$ \\
\hline Official, clerk & 2 & $1.0 \%$ \\
\hline
\end{tabular}

Source: own elaboration

Assuming possibility or willingness of translating personal preferences into professional decisions, answers provided by members of the senior management or supervisory boards as well as by mangers may provide some indication of the evolution of the approach to increasing the role of digitization not only from the perspective of individual users of banking services, but also in relation to business entities and institutions.

The last distinguishing feature, according to which the respondents were characterized, is the place of residence of a given person, as presented in Table 4 .

Table 4. Number and share of respondents by the place of residence.

\begin{tabular}{|l|r|r|}
\hline $\begin{array}{l}\text { Place of residence } \\
\text { (declared by respondents) }\end{array}$ & $\begin{array}{c}\text { Number of } \\
\text { respondents }\end{array}$ & $\begin{array}{c}\text { Share of } \\
\text { respondents }\end{array}$ \\
\hline Poland & 176 & $88.0 \%$ \\
\hline Europe (excluding Poland) & 20 & $10.0 \%$ \\
\hline Asia & 3 & $1.5 \%$ \\
\hline Latin America & 1 & $0.5 \%$ \\
\hline
\end{tabular}

Source: own elaboration

\subsection{Results of the survey by the selected characteristics of the research sample}

Based on 200 complete sets of answers that have been asked in the survey conducted for the purposes of this study, it should be stated that the respondents show an enthusiastic approach to the use of the mobile banking services. Among 200 surveyed Internet users, 174 people admitted that they use mobile banking services on a daily basis, which is $87 \%$ of the total number of respondents. It is also worth noting that if only the answers of people who declare their place of residence as Poland, the enthusiasm for mobile solutions used in banking is even greater $-88.6 \%$ of respondents living in Poland stated that they use the mobile banking services. Additionally, it can be seen that in the group of men $89 \%$ of people declare using mobile banking services. The share of mobile banking users among surveyed women is lower than in the group of men and amounts to $83 \%$. The same tendency was observed in 2017 in the United Kingdom during the research conducted by VocaLink in February 2017 in the United Kingdom on 2,000 respondents, where approximately $21 \%$ of surveyed men confirmed the use of mobile payments, compared to $12 \%$ of women [24].

It is worth noting that the data published by the recognized, globally operating research groups, unambiguously indicates the high position of Poland among countries where the use of mobile banking solutions is widespread. For example, in a global survey conducted by Ipsos in 2017 and 2018 on a sample of over 25,000 Internet users from around the world aged 18-64, a question about the anticipated willingness to use mobile payments via their smartphones was asked. The published results indicate that $78 \%$ of the Internet users in Poland are willing to use their smartphones to make mobile payments next year (2018). The registered result (78\%) placed Poland on the high, fifth place among all analysed countries, just behind China (94\%), Indonesia (93\%), India (83\%), Kenya (79\%), and before countries such as South Korea (75\%), Sweden (64\%), United States (45\%), Great Britain (39\%), France (31\%), or Japan (29\%) [26]. In addition, cyclic surveys, conducted in Poland by well-known portal Jestem.Mobi, indicate that the use of banking services 
through mobile devices is one of the most popular online daily activities performed by the Internet users in Poland, in addition to activities such as corresponding via e-mail, using social networking portals, reading articles and watching movies [7].

Extending the analysis of the respondents' answers to the analysis of the dependence of using mobile banking services on the age of respondents, it should be noticed that in the group of people aged 19 to 29 all respondents declared that they use mobile banking services on a daily basis, while 88,6\% of respondents between 30 to 49 years old declared that they are active users of mobile banking services. The lower mobile banking services penetration rate $(66,7 \%)$ can be observed in the age group of people aged between 50 and 69 years.

\subsection{Main concerns related to the use of mobile banking services according to surveyed Internet users}

The key element of the research conducted for the purposes of this study was to examine what kind of concerns related to the use of mobile banking services are the most popular. A surprising result from the analysis of registered responses is the fact that the most common concern associated with the use of mobile banking services was the one related to the safety of personal data. It should be noted that $39 \%$ of respondents indicated that they had concerns about the security of personal data. However, only $7 \%$ of the surveyed Internet users expressed concerns about the security of transactions. Thus, it is worth noting that according to the study carried out by TNS on behalf of the European Commission, $73 \%$ of the Internet users in the European Union are afraid that their personal data processed via websites is not adequately protected, and $65 \%$ of the Internet users think that their personal data are not sufficiently secured by the public institutions. According to the data published by TNS, abuse related to inadequate protection of personal data and the security of online payments are currently the most important problems of Internet users [1].

The analysis of the responses by gender shows that $40 \%$ of female respondents and $36 \%$ of male respondents have concerns about the security of personal data. In Statista survey conducted in 2016 in the United States of America (USA) among over 1,000 adult English-speaking residents, concerns about the safety of personal data was also the most frequently declared response (followed by the fear of fraud), with the distribution of responses by gender being almost even $-47 \%$ for men and $46 \%$ for women [24].

At the same time, when analysing the answers provided in the surveys conducted for the purposes of this study, $38 \%$ of respondents indicated that they have no doubts or concerns related to the use of mobile banking. Lack of trust in technologies used in popular mobile banking solutions was expressed by $13 \%$ of Internet users. The summary of all answers received to the question 'What are your main concerns about using mobile banking services?' is illustrated in Table 5.

Table 5. Concerns about using mobile banking services (summary of results)

\begin{tabular}{|l|r|}
\hline \multicolumn{1}{|c|}{ Concern (answers to multiple choice question) } & $\begin{array}{c}\text { Share of } \\
\text { respondents }\end{array}$ \\
\hline I have concerns about the security of personal data & $39.0 \%$ \\
\hline I have no concerns / doubts related to the use of mobile banking & $38.0 \%$ \\
\hline I do not trust the technology used & $13.0 \%$ \\
\hline I have other concerns and doubts & $9.0 \%$ \\
\hline The use of mobile banking is inconvenient & $9.0 \%$ \\
\hline All my needs related to banking services are met in a different way & $7.0 \%$ \\
\hline I have concerns about the security of transactions & $7.0 \%$ \\
\hline I prefer cash payment & $2.0 \%$ \\
\hline The use of mobile banking is too complicated for me & $1.5 \%$ \\
\hline I do not have mobile devices and / or other necessary means & $0.5 \%$ \\
\hline Source: own elaboration &
\end{tabular}

It is also worth noting that only $9 \%$ of Internet users perceive the inconvenience of using banking services via mobile devices (e.g. too small screen or an uncomfortable keyboard of particular mobile device) as a potential obstacle in making a decision to use mobile banking solutions.

Taking into account the fact, that the most important concern of using mobile payments is security of personal data, the key factors of that state should be investigated. Apart from the increased awareness of respondents, which could undoubtedly have been affected by the implementation of the new EU data protection regulation (Regulation (EU) 2016/679 of the European Parliament and of the Council of 27 April 2016 on the protection of natural persons with regard to the processing of personal data and on the free movement of such data, and repealing Directive 95/46/EC (General Data Protection Regulation)), other factors may also be important, including the users' notions about possible consequences of unauthorized access to their personal data. By interviewing the randomly selected respondents of the survey described in this article, the following possible reasons of having concerns about personal data breaches have been distinguished:

- risk of becoming a victim of a fraud,

- unauthorized usage of online identity for fraudulent purposes,

- information being used without data subject's knowledge,

- risk of sharing personal data with various third parties (including companies and marketers)

- putting personal safety at risk,

- unwanted loss of personal data,

- risk of reputation damage,

- becoming the victim of some kind of discrimination,

- risk of misunderstanding of data subject's views, opinions or behaviors.

An interesting perspective of looking at the concerns raised by the Internet users is their attitude to payment in cash. It could be easily observed that preference to use cash payments among users surveyed for the purposes of this article is not a significant obstacle preventing them from using mobile payments. Only $2 \%$ of surveyed Internet users indicate that they prefer cash payments over mobile payments, but this certain result may be particularly dependent on the fact, that almost all respondents not only have post-secondary education, but also they are living in large cities and have established professional position. For example, taking into account the results of the above mentioned Statista survey in the USA from 2016 it could be noticed that $24 \%$ of respondents generally prefer to pay in cash [24]. Additionally, it is worth noticing that concerns about the ease of use of mobile banking services, which are common in the USA (38\% of respondents of Statista survey declared that they do not use mobile payments, because they know too little about it or have not familiarized themselves with it [24]) were hardly observed.

While analyzing surveyed Internet users, who have simultaneously declared the following:

- I do not trust the technology used,

- I have concerns about the security of personal data,

it was observed that $66 \%$ of this group of respondents are generally interested in new developments but they are not sure about all new options and their security standards. This attitude to increasing role of digitization in the banking and financial sector was described as neutral. In turn, $17 \%$ of the above defined group of respondents declared that they are highly interested in new solutions, which make their financial routines easier and safe (they feel positive about the increasing role of digitization in the banking and financial sector). The remaining $17 \%$ of respondents stated that they are happy with their traditional banking and payment solutions and do not want anything else (presenting negative attitude to increasing role of digitization in the banking and financial sector). Additionally, it is worth noticing, that both respondents from the first group with positive attitude and respondents from the second group with neutral attitude declared, that their main payment method is paying with payment cards (including credit cards). Respondents, who feel negative about the increasing role of digitization in the banking and financial sector, pay for everything in cash or using traditional bank transfers. 


\section{Conclusions}

The synthetic review of electronic banking services presented in this article, from terminal banking through the Internet banking to a very wide and diverse category of mobile payments, gives the basis to conclude that we are currently witnessing a revolution in making payments, especially non-cash ones. The article shows, that Poles have definitely liked cashless transactions, and this is among others the result of nationwide educational and information campaigns such as polskabezgotówkowa.pl and wartobezgotówkowo.pl. The majority of non-cash transactions in Poland are is carried out with contactless cards using NFC and HCE technology.

The increase in the number of smartphone users and other mobile devices, a convenient, fast and intuitive way of conducting transactions undoubtedly affect the dynamic development of this modern form of payment, which is evidenced by the increase in the number of contactless payments.

Nevertheless, the significant correlation between the number of mobile devices per capita and mobile payments adoption rate was not yet discovered.

From the global perspective it should be remembered, that the popularity of mobile banking services is constantly growing. In 2017, the number of mobile proximity payment users stood at 721.2 million worldwide and is projected to surpass 1 billion users in 2020 [23] - this trend is illustrated in the Figure 2 (data for years 2018-2021 is forecasted). Additionally, according to the predictions of experts from Capgemini and the global bank BNP Paribas, co-authors of the World Payments Report 2018 , the global use of non-cash transactions will increase and can reach annual growth (CAGR) of $12.7 \%$ [29].

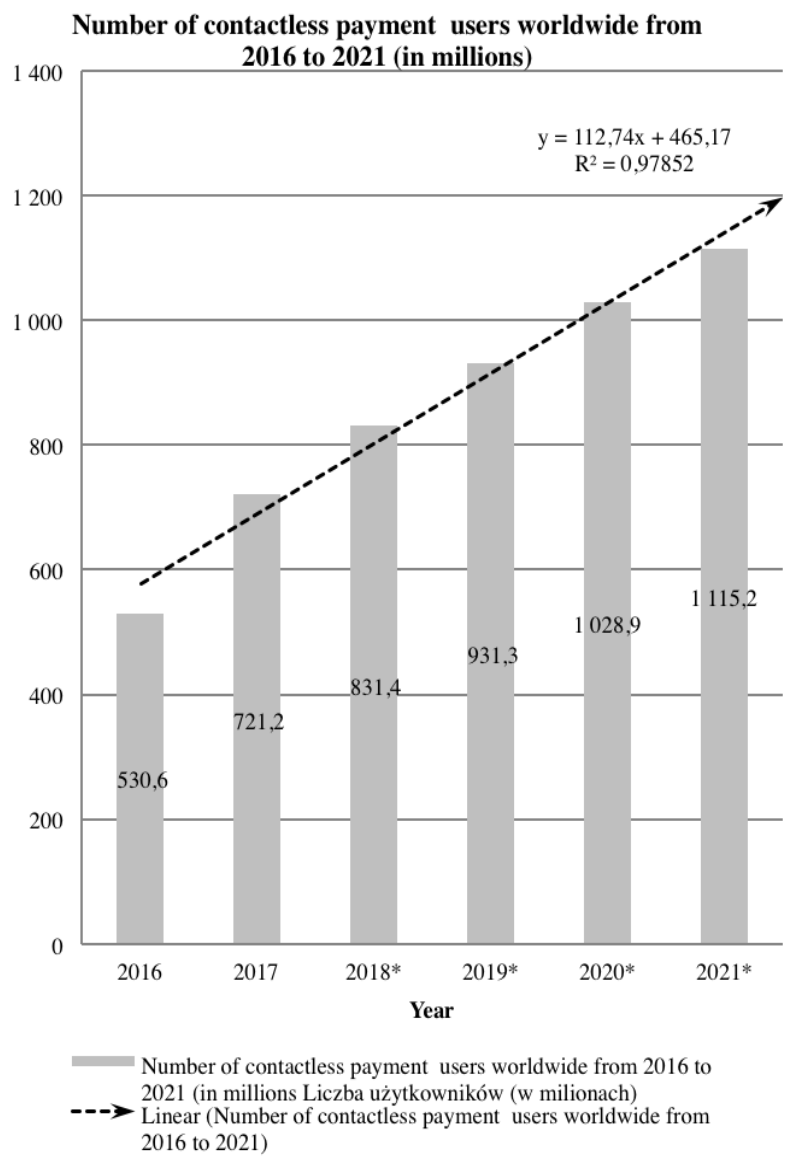

Fig. 2. Current state and predictions of number of contactless payments (globally)

Currently, non-cash payments can be made not only with contactless cards or with mobile devices such as popular smartphone or tablet, but also with wearable devices such as smartwatches, fitness trackers, smart clothes or even rings all fitted with contactless payment technology. While the market for wearable payments is still in its infancy, initial indicators are that consumers are increasingly keen to embrace the advantages of using NFC technology in wearable devices. Moreover, clients are hungry for a diversity of payment options that support different needs, and widespread acceptance for convenient 'frictionless' payment solutions is growing apace [28]. According to Statista survey, conducted in 2017 in Sweden among over 1,000 adult, $34 \%$ of respondents see themselves using thumbprint scanning for carrying out the payment. Additionally, it could be noticed that $20 \%$ of respondents generally could prefer to pay by pressing watch or other accessory against the payment terminal. Moreover, $18 \%$ of respondents see themselves using eye scanning for payment transaction. Similarly, $17 \%$ of respondents would prefer paying by scanning a chip that has been surgically inserted into arm [27].

It should also be noted that mobile payments, due to the modern technologies used, are much more secure than transactions made with traditional payment cards [6]. The attitude of Poles towards innovative solutions used in order to pay via the most popular mobile devices is a good predictor for the further development of this form of payment. According to the National Bank of Poland almost 40.2 million payment cards (including credit cards) are in Polish portfolios, where, $81.7 \%$ of them are contactless cards [20]. Poles are enthusiastic about making transactions via dedicated mobile applications, which enable diverse forms of authorization, what can be evidenced by the growing popularity of the Blik system. Along with the growing popularity of innovative payment solutions, modern methods of authentication are also developing - one of them is biometrics, which is already very popular among consumers. Almost $83 \%$ of them believe that it is a secure form of authentication (an increase of 23 percentage points over a year) [9].

Thanks to the possibilities offered by tokenization, purchases using any device connected to the Internet: a smartphone, tablet or wearable device are becoming more and more secure. For example, Visa and the Greek bank NBG (National Bank of Greece) recently announced the launch of a project carried out jointly with Folli Follie and Links of London regarding the launch of jewelry with payment function [9]. In the near future, thanks to tokenization or thanks to other innovations, so numerous in recent years, it will be possible to pay conveniently from cars or via home appliances.

The occurrence of significant concerns about unauthorized access to personal data, which is observed both in Poland and in other countries around the world, should be an important tip for bank managers. Moreover, as it can be seen on the example of the BLIK system, if the banks cooperate with each other, they create space for the emergence of new forms of payment and at the same time they may contribute to the creation and dissemination of one widely accepted (e.g. at the national level) mobile payments standard. Undertaking coordinated educational activities in relation to the protection of personal data when making mobile payments may affect the gradual decline in the share of people who are afraid to use mobile banking services due to data privacy concerns. However, having in mind the cyber security itself, it is also important to remember to develop, take and constantly monitor diverse preventive actions to reduce the risk of personal data breach.

The data and comments presented in this article indicate that professionally active, educated people are more enthusiastic about mobile payments than the average citizen of a given country. However, in order to be able to draw broader conclusions on this subject, it is necessary to conduct statistically representative studies. Additionally, it should be emphasized that the rapidly changing global image of mobile banking requires fast and frequent publication of the registered results, mainly in order to fairly reflect the pace of key changes in this area.

The current decade has witnessed momentous changes and various innovations in mobile banking services and with emergence of an increasing propensity to use mobile payments 
(especially among professionally active, educated people) the transformation shall continue. Forecasting the future of contactless payments is a subject to significant mistakes, resulting primarily from the high dynamics and unpredictability of not only technological progress, but also civilization as a whole. However, based on the predictions of report and experts citied in this article, it can be assumed that the popularity of mobile payments, not only in Poland but also in the world, will systematically grow.

\section{References}

[1] Cisco Visual Networking Index: Forecast and Trends, 2017-2022, Cisco Systems, 2018, 1-7.

[2] Europeans' attitudes towards cyber security - Report, Special Eurobarometer 464a, European Commission, September 2017, 5.

[3] Financial Technology, Information on subsectors and Regulatory Oversight, April 2007, w: United States Government Accountability Office Report to Congressional Requesters, GAO Highlights GAO-17-361.

[4] FinTech Report 2019, Statista Digital Market Outlook - Market Report, December 2018

[5] Guzek E., Ślązak E.: Innowacyjna bankowość Internetowa: Bank Web 2.0. Wolters Kluwer, Warszawa 2012.

[6] Jagodzinska-Komar E.: Innowacje w kartach wielowalutowych i mobilnych płatnościach zbliżeniowych. Zeszyty Naukowe Państwowej Wyższej Szkoły Zawodowej w Płocku Nauki Ekonomiczne, 2016, t. XXIII

[7] Jeffus B., Zeltmann S., Griffin K., Chen A.: The future of mobile electronic payments. JCS 25(3\&4)/2017.

[8] Krzysztoszek M.: Bankowość elektroniczna w teorii i praktyce. Materiały edukacyjne dla środowiska szkolnego. Komisja Nadzoru Finansowego, Warszawa 2017

[9] Mikowska M., Skalna A., Siwiński K.: Polska.Jest.Mobi 2018, Jestem.Mobi 2018.

[10] Q4 2018 Global Digital Statshot, Hootsuite and We Are Social, October 2018.

[11] Rzepka A.: Analiza i ocena funkcjonowania bankowości elektronicznej w Polsce na przykładzie ofert wybranych banków. Studia Ekonomiczne Prawne i Administracyjne 2/2017.

[12] Ślązak E.: Bankowość elektroniczna. Świat Bankowości. Difin, Warszawa 2018, 266-292.

[13] Tam C., Oliveira T.: Literature review of mobile banking and individual performance. International Journal of Bank Marketing 35(7)/2017, 1044-1067.

[14] https://polskabezgotowkowa.pl [26.11.2018].

[15] https://polskistandardplatnosci.pl/ [8.12.2018]

[16] https://wartobezgotowkowo.pl/dla-mediow/ [4.12.2018]

[17] https://www.cisco.com/c/m/en_us/solutions/service-provider/vni-forecasthighlights.html [8.01.2019].

[18] https://www.cs.pl/produkty/rodzaje-kart-plastikowych/ [5.12.2018]

[19] https://www.komputerswiat.pl/artykuly/redakcyjne/nfc-jak-bezpieczne-saplatnosci-zblizeniowe/r93ftq8 [4.12.2018].
[20] https://www.nbp.pl/systemplatniczy/ocena/ocena2018_1.pdf [11.01.2019].

[21] https://www.pekao.com.pl/mis/karty_platnicze/karta_debetowa_wielowalutowa _mastercard_business/?s,main,language $=$ PL [4.12.2018].

[22] https://www.reuters.com/brandfeatures/venture-capital/article?id=32545 [10.01.2019].

[23] https://www.statista.com/statistics/557959/global-mobile-proximity-paymentusers/ [04.12.2018].

[24] https://www.statista.com/statistics/639729/reasons-for-not-using-mobilepayment-usa-by-gender/[12.12.2018].

[25] https://www.statista.com/statistics/727999/mobile-payments-by-gender-unitedkingdom/ [12.12.2018].

[26] https://www.statista.com/statistics/934055/likelihood-of-online-users-mobilepayment-system-usage-country/ [12.11.2018].

[27] https://www.statista.com/statistics/880472/willingness-to-use-futuristicpayment-methods-in-sweden/[21.11.2018]

[28] https://www.smartpaymentassociation.com/index.php/liste-documents/publicresources/position-papers/612-wearable-tech-growing-payment-opportunity-spajuly-17/file [21.11.2018].

[29] www.worldpaymentsreport.com [21.11.2018]

\section{M.Sc. Jolanta Panas}

e-mail: jolanta.panas@gmail.com

Ph.D. student of Management at Warsaw School of Economics. In 2007 she completed her dual master studies in Finance and Banking at Warsaw School of Economics and Johannes Gutenberg University in Mainz, from that time she was employed in international companies in the domain of property valuation and management. Her research interests include finance, REIT, property valuation and management.

ORCID ID: 0000-0003-3673-6370

M.Sc. Katarzyna Maria Wilczyńska

e-mail: k.m.wilczynska@gmail.com

Ph.D. student of Management at Warsaw School of Economics. In 2008 she completed her master studies in Finance and Banking as well as in Quantitative Methods in Economics and Information Systems at Warsaw School of Economics. Her research interests include evolution, adoption and security of mobile banking, project management and methodology of performing IT audits in financial sector.

ORCID ID: 0000-0002-5730-6348
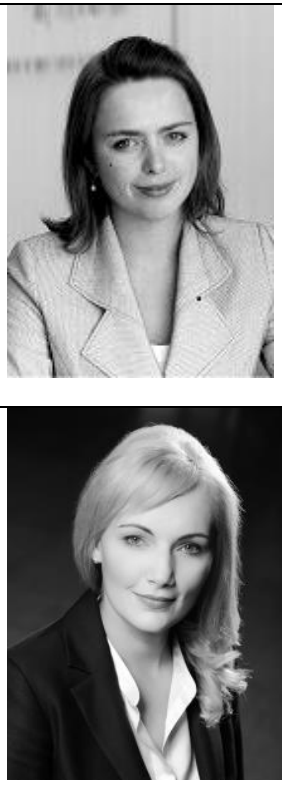

otrzymano/received: 14.01 .2019

przyjęto do druku/accepted: 28.02 .2019 